\title{
IV. MICROORGANISMS AND ENVIRONMENT
}

\section{PATHOGENIC BACTERIA IN WATERS AND DRINKING WATER- ASSOCIATED BIOFILMS}

\author{
Zvezdimira Tsvetanova, Hristo Najdenski
}

\begin{abstract}
In this review, the dissemination of bacterial pathogens in natural waters and the mechanisms of their transmission in drinking water, and the role of water-associated biofilms for their survival or growth are discussed. The current state of the studies on biofilm-formation potential of the emerged pathogens in drinking water and the role of interspecies interactions for attachment and survival of pathogenic bacteria in the biofilm community is summarized. The contribution of the biofilms for increasing antimicrobial resistance of pathogens is discussed.
\end{abstract}

Key words: bacterial resistance, biofilm, quorum sensing, pathogenic bacteria, drinking water

\section{Introduction}

Biofilms are attached microbial communities, ubiquitous in natural waters and purified drinking water $[1,18,34,36,72]$. Biofilms in drinking waters are object of increasing scientific interest during the last two decades because they represent one of the factors for deterioration of the bacteriological quality of drinking water, however, the provision of clean and safe drinking water in sufficient quantity is a basic human right $[19,43,76,77,79]$.

While the problems of choosing a drinking water source and technologies for drinking water purification and disinfection have had their optimal solutions, the biofilms that develop on the surface of pipelines and facilities in contact with drinking water still are object of scientific inquiry $[20,47,63$, $68,69,75]$. Biofilms provide favorable conditions for settlement and survival of bacteria, including pathogenic bacteria, that can enter the drinking water as a result of erosion and sloughing of the biofilm and can pose a health risk during water consumption and cause social and economic damages [18, 27, 36, 37, 72].

\section{Transport and dissemination of pathogens in water}

Microbial pathogens enter the surface water through different point and diffuse sources of pollution, such as agricultural runoff, discharge of partially treated or untreated sewage water, septic tanks, excrements of wild animals, birds and livestock $[25,32,40,41]$. Subsequently they can attach and accumulate in bed sediments and in flocculated (suspended) sediments, i.e. flocs, which can be transported by the river flow, especially during heavy rains and floods. The settling of the flocculating particles assists accumulation of pathogenic bacteria and viruses in the bed sediments $[24,40]$. The transport of pathogens by suspended sediments affects the quality of water for drinking purposes, irrigation and recreation, and owing to the potential effects on human health could have substantial impact on economic and recreational activities in riverside areas [23, 24].

A variety of biological, physical and chemical factors determine the fate of pathogenic bacteria in aquatic ecosystems. It is found that the different pathogens, even strains of one and the same species, have a different capability to survive and persist in the water column and sediments [13, 40, 74]. Comparative studies indicate that the density of pathogens in the bed sediments is several orders of magnitude higher compared to the water column, and that pathogen survival in sediments is much longer [48]. The analyses of E. coli, Salmonella spp., Vibrio spp. reveales a greater abundance in the sediments than the water column and larger number of culturable bacteria in the suspended sediments in comparison with the surficial bed sediment fractions $[13,40]$. The association of pathogens with the flocculating particles of the suspended sediment provides environment and means for their survival and transportation, as the secreted extracellular bacterial polymers, which constitute a significant portion of the flocs, play an important role in their capture and attachment [13]. These data support the paradigm that the association of pathogens with the sediment particulates enhances their survival and circulation in aquatic environment.

Identifying the sources of pathogenic contamination in natural waters is difficult due to diffuse nature of discharges, transiency of the loads and fluctuations caused by the processes of transport and transformation. Furthermore, the significant interactions between microorganisms, nutrients and 
particulates that occur in the water column complicate the predicting the fate and potential infectivity of the human and zoonotic pathogens $[40,74]$. As a result of co-flocculation with organic matter and mineral particulates in water the pathogens become potentially more protected against the biotic stress (i.e. predators) and abiotic stress (e.g. UV, temperature). The flocs contain and retain nutrients, allowing survival/growth of pathogens and their transmission via deposition on the banks or forming stable bed sediment. As a result of natural disasters (storms, heavy rains and floods) the bed sediments can be re-mobilized and can release pathogens back in the water column quite long after the climatic event [40, 74].

The enteropathogenic bacteria E. coli $O 157$ is frequently found in the intestines of healthy cattle and ruminants that can contaminate surface waters and irrigated lands by their excrements or because of the pathogen mobilization in the runoff waters from pasture [11, 25, 26]. Campylobacter coli and Campylobacter jejuni are ubiquitous in surface waters affected by agricultural activities or discharge of waste waters $[9,32,25,26]$. Since the thermophilic and microaerophilic nature of campylobacters and their sensitivity to environmental stress limit their growth and survival in water, the changes in their number in water are due to the contamination by poultry and livestock. The sewage is the main source of campylobacters in natural waters, while ground waters provide favourable conditions for their survival [26]. The data of Jokinen et al. (2011) confirm the potential sources of pathogenic contamination in natural waters and demonstrate more frequent isolation of Campylobacter spp. from faeces, sewage and river water compared with Salmonella spp. and E. coli O157:H7 [25].

The enteropathogenic bacteria Yersinia enterocolitica also enter the water as a result of faecal contamination by wild animals, mammals and birds [30]. Because of its resistance to low temperatures $Y$. enterocolitica cells survive in natural waters for several weeks, which is a longer compared to the E. coli survival time [71].

Atypical (non-tuberculous) mycobacteria are inhabitants of various aquatic ecosystems unlike the tuberculous mycobacteria, which are not transmitted via the water. The term "Mycobacterium avium complex" is generally used to describe a pathogenic non-tuberculous mycobacteria, including $M$. avium and $M$. intracellulare. The tolerance to disinfectants as chlorine and ozone and a higher temperature allows their survival during the water treatment process and determines their detection in drinking water supply systems and building installations. In natural waters, atypical mycobacteria most often are found during the summer months, while in drinking water supply systems they are detected mainly in the hot water installations and in the most remote pipeline parts [33, 40, 63, 64].

Legionella pneumophila is ubiquitous in surface waters because of its tolerance to environmental stress (the temperature from 5 to $63^{\circ} \mathrm{C} ; \mathrm{pH}$ from 5 to 9.2 , proliferation at temperature from 20 to $42^{\circ} \mathrm{C}$ ) and capability to adapt to different ecological niches [38, 69, 79]. L. pneumophila, M. avium, Ps. aeruginosa, St. aureus are natural aquatic inhabitants and since the faeces are not their common source, E. coli is not appropriate indicator of their presence in the water [38].

\section{Dissemination of pathogens in drinking water}

Untreated natural waters are reservoir of obligate pathogenic bacteria and opportunistic ones, such as Aeromonas sp., Acinetobacter spp., Bacillus cereus, Flavobacterium spp., Moraxella sp., Pseudomonas spp., which enter the drinking water as a result of inadequate water treatment for their removal, insufficient disinfection or recovery of the injured cells in the biofilms existing on the surface of pipes and equipment in the drinking water supply systems (DWSS) [7, 37, 72, 76]. Pathogens re-growth in drinking water, their survival or growth in waterassocited biofilms and the accidental contaminations of the water supply systems with untreated or fecal contaminated water due to leakage or mechanical damages of the pipelines are the main reasons for deterioration of the bacteriological water quality [34, $37,38,43,68]$.

It is well known that the obligate pathogens quickly lose their viability and virulence outside the host, can not multiply and decay over time, while the opportunistic pathogens as Mycobacterium avium, Legionella pneumophila, Pseudomonas aeruginosa and Aeromonas hydrophila are able to propagate in drinking water and may cause infections and diseases mainly of immuno-compromised people [33, 49, 61, 79]. The M. avium group and L. pneumophila are opportunistic pathogens, which found ecological niches in the drinking water and in the hot water supply systems [32].

Zoonosis Shiga toxin-producing E. coli O157:H7 has emerged as an important food-borne or water-borne pathogen, as approximately $10 \%$ of the reported outbreaks are related to the consumption of contaminated drinking water from private wells or small water supply systems [11]. Viable cells of 
E. coli $0157: H 7$ are isolated from water sources, which met all hygienic requirements for drinking water quality [57]. They survive long (from 14 to 64 days) depending on the content of protozoa and heavy metals in the water [2]. The survival and growth of Legionella pneumophila in drinking water are significantly influenced by the co-existing inhabitants of the microbial community [46]. $Y$. enterocolitica serotype $O: 3$ is reported as a causative agent of infection disease owing to the consumption of raw water, while $Y$. enterocolitica serotype $0: 8$ - as a result of the consumption of contaminated food or water [50, 71]. Campylobacter spp. are responsible for $14 \%$ of water-borne outbreaks of diseases in England and Wales, related mainly to private water sources.

The presence of Shigella sonnei in drinking water is associated with inadequate water treatment and disinfection. Notwithstanding the frequent occurrence of Pseudomonas aeruginosa in natural waters, its presence in drinking water is most often related to poor chlorination (because the pathogen sensitivity to disinfectant) [79]. Assessing the capability of the pathogenic E. coli O157, Vibrio cholerae and Ps. aeruginosa to grow in drinking water the authors found a poor correlation with the concentration of assimilable organic matter in the oligotrophic water environments, but a strong impact of the qualitative composition of the organic matter [70].

Involvement of pathogenic bacteria in the drinking water-associated biofilms

Attached microbial biomass of the biofilms represents up to $95 \%$ of the active biomass in drinking water supply systems [19]. The biofilms in the DWSS are formed primarily by the autochthonous aquatic microflora without particular hygienic and health importance. [79]. Specific microenvironments in the biofilm structure, however, can provide niches for survival or prosperity of water-borne pathogenic bacteria, ensure protection against predatory protozoa and environmental stress, and create opportunities for cooperation and cell recovery of the bacteria injured through disinfection [19, 34, 37]. Detachment of bacteria from the biofilm matrix or sloughing of larger pieces of the biofilms may increase bacteria number in drinking water. In this way, biofilms can be a source of continuous bacterial contamination of the drinking water, including the dissemination of opportunistic, human and zoonotic pathogens [36, 37, 43, 72].

The opportunistic pathogens Ps. aeruginosa, Legionella spp., Serratia spp., Klebsiella spp., Flavobacterium spp. usualy absent in drinking water, but can enter the DWSS due to accidents or inadequate chlorination. Although the tendency for their propagation seem limited, the specific conditions in domestic water supply installations, such as an increased ratio between contact surfaces and water volume (the $\mathrm{S} / \mathrm{V}$ ratio), higher temperatures, longer periods of stagnation, type and age of pipe materials, can promote their attachment, survival and/or propagation in the water-associated biofilms $[45,46,61]$.

Ps. aeruginosa is a typical biofilm-forming bacteria, that is tolerant to different physical conditions, non-fastidious to nutrients and as a result can colonise almost any artificial surface. It is able to be primary colonizer, but can incorporate in already existing biofilms; may participate in formation of multi-species biofilms where may become dominant species $[45,79]$.

In oligotrophic environment of the DWSS, the survival and reproduction of L. pneumophila depends on the partnership with microorganisms that ensure essential amino acids and organic carbon $[45,46,61]$. Therefore, multi-species biofilms are a perfect ecological niche for L. pneumophila and the pathogen can involve into the existing biofilms as secondary colonizer instead to attach to uninhabited surfaces. The free-living amoeba Acanthamoeba spp., Naegleria spp., Hartmanella spp. and other protozoa like ciliate Cyclidium spp. and Tetrahymena pyriformis are still considered to be a key factor in survival and proliferation of Legionella in environment, despite the ongoing discussion whether the biofilm-associated legionellas require protozoan host for their reproduction or can replicate independently. However, there are evidences, that the growth and biofilmformation of Legionella pneumophila can be inhibited by some Gram (-) bacteria, including Ps. aerugionosa, Ps. fluorescens, A. hydrophila, Burkholderia cepacia, Stenotrophomonas maltophilia [46, 61, 69]. The biofilm-associated legionellas can be released from the biofilm and contaminate water, as the infection is predominantly obtained by inhalation of contaminated aerosols from taps, showers or swimming pools.

Atypical mycobacteria $M$. avium can propagate in appropriate aqueous habitats, especially in the water-associated biofilms. In the DWSS, their number can increase due to the cleaning procedures for biofilm removal through flushing water or reverse flow [33, 49]. The mycobacteria are relatively resistant to disinfection and can occur in the DWSS with high residual chlorine content. Culturable cells of M. avium and L. pneumophila can survive in the biofilm at least from 2 to 4 weeks, even under turbulent flow conditions [38]. Norton et al. (2004) detected that the biofilm survival of $M$. 
avium is dependent on the type of material as a surface for attachment and the content of nutrients and disinfectant [49]. Torvinen et al. (2007) detected participation of atypical mycobacteria in the biofilms and loose deposits, as their number correlate with the content of assimilable organic carbon in water and it is the greatest in the distant pipe sections of the DWSS [63,64].

Aeromonas hydrophila is isolated from the biofilms in water supply systems for potable or recycled water and the number of attached cells depends on the biofilm biomass, despite the growth capability under limited nutrients content [6].

The enteropathogenic E. coli O157:H7 can form biofilm over abiotic and biotic surfaces outside the host $[29,55,67]$, while the available information on Yersinia enterocolitica is quite limited. Novoslavskij et al. (2013) have not found significant difference in the biofilmforming ability of the 19 strains of Y. enterocolitica 4/O:3 bioserotype, which is a major causative agent of illness in Europe [50]. Helicobacter pylori cells present in drinking water associated biofilms in a viable but-non culturable state. This pathogen attaches better in mixed bacterial consortia compared to its single-species biofilm, which supports the assumption that the indigenous aquatic bacteria assist the pathogen embedment by providing a microaerophilic conditions and the binding biomolecules [15].

Campylobacter jejuni attaches more readily to hydrophobic surfaces and its biofilm-forming properties depend on temperature, oxygen and nutrients contents [52]. The pathogen is detected in the water-associated biofilms in DWSS and watering systems in poultry farms, and its biofilm-forming capability is weaker compared to the ones of Ps.aeruginosa, E. coli and St. simulans. Campylobacter jejuni is secondary colonizer and has insignificant effect on development of mixed biofilms, although a quorum-sensing activity is detected during co-existence with certain bacteria. The pathogen showed high biofilm formation index in co-existence with Enterococcus faecalis or St. simulans [65].

\section{biofilms \\ Bacterial interactions in the multi-species}

Over a long period, the biofilm-forming capability of pathogenic bacteria attracted much more attention mainly in medical and food production fields than in water engineering, where most studies considered single-species biofilms [16]. Since biofilms in nature comprise a great number of microbial species, but it is known that the insights gained from the studies on their planktonic growth or single-species biofilms cannot readily be extrapolated to multispecies biofilm consortia, in the recent years there has been a shift in focus toward examining the complexity and interactions in multispecies biofilms $[1,14,16,53]$. Substantial research efforts are directed at clarifying the social relationships and the driving forces in biofilm communities and at assessment the damages and benefits for individual species-partners in the multispecies biofilms. Laboratory examinations are carried out mainly with single-species of bacteria which were isolated from natural habitats - soil, natural and waste water, dental plaque and artificial implants $[1,54,58]$.

In biofilm, the attached bacteria are influenced by environmental conditions, as well as by diversity of the microbial species co-existing in the same habitat. It is found that there exist complicated interactions in the attached multispecies communities, which are based on cell-to-cell contacts, as well as on a set of metabolic products which are excreted in the environment. The members of the multispecies bacterial biofilm can affect each other in different ways: antagonistically (by competition for the substratum or by production of inhibiting substances), synergistically (by co-metabolism, induction of biofilm potential, increased resistance), as well as to remain neutral $[8,14,16,53]$. Predominantly synergetic interactions are detected: higher biomass production by the multispecies biofilms compared to the corresponding single-species biofilms; predominance of one species in the biofilm consortium, but in obligatory presence of other species, so that a strong synergetic effect is achieved [54]. It has been shown that the intergeneric coaggregation may play a significant role in the multispecies biofilm formation. For instance, Acinetobacter calcoaceticus, which is weak biofilm producer, performs a bridging function in the multispecies biofilm formation in drinking water, while its absence results in a decrease of biofilm biomass [59]. Similar role is played by Sphingomonas natatoria in biofilms in natural waters [42].

The conducted studies of interspecies interactions in biofilms are mainly based on the model of participation of the defined partners: Andersson et al. (2008) studied binary and multispecies biofilms of 13 bacterial species, common in the wastewater treatment systems [1]; Simoes et al. (2007) investigated the interactions in binary biofilms of 5 bacterial strains isolated from drinking water [58]. It has established cooperative advantages, neutral or antagonistic interactions and 
demonstrated their importance for structural and functional characteristics of the biofilm community.

It is also found that intra- and interspecies interactions have a profound influence on the development, structure and physiology of the mixed bacterial biofilms. For example, the participation of an E.coli O157:H7 strain in the mixed biofilm together with Salmonella enterica is dependent on the companion strain properties in terms of expression of EPS production [73], and the adhesion of nonbiofilm-forming E.coli O157:H7 strains due to the biofilm-forming partner strains [67]. Klayman et al. (2009) found that a water-borne E.coli O157:H7 strain required a colonizing partner since planktonic cells were unable to attach alone, but were able to coadhere with $P$. aeruginosa and attached easier to the surfaces precolonized with Ps.aeruginosa [29]. There are data that biofilm formation potential of Campylobacter jejuni is strain specific and relies on the bacterial populations in the mixed biofilm community, which prolongs pathogen survival in external environments and favours its culturable state in the mixed biofilm versus the viable but not culturable state in the monoculture biofilm $[8,22,65]$.

There is sufficient data that the regulation of biofilm formation process is mediated by interbacterial signals - quorum sensing (QS) by means of small diffusion active molecules produced by the bacteria, called autoinducers. The autoinducers accumulate in the environment and after reaching the threshold concentration they diffuse back into the bacteria and regulate the transcription of specific genes. Inter-bacterial signaling allows to bacteria to coordinate the gene expression, and through cell density - the behavior of the entire community [10, $62,78]$. The quorum sensing has significant importance for biofilm formation potential of many bacteria. The biofilm structure, where the cells are close one to another, supports cell-to-cell signaling. The results from this multicellular behavior, such as biofilm formation, swimming and swarming, contribute to bacterial pathogenesis. For example, it was found out QS-control on swimming and swarming mobility of Yersinia enterocolitica [3] and that the flagella are important for the initializing of the process of biofilm formation [28].

\section{Biofilm control strategies}

It is generally known, that the attached bacteria exhibit greater tolerance to antimicrobial agents compared to the planktonic cells in the water [7, 34, 35, 39]. Depending on the type of bacterial species and the type of biocide it has been found that achievement of the same degree of reduction of the attached cells requires from 1 to 1000 times higher concentrations of biocide and from 20 to 2160 times longer reaction time compared with the planktonic cells [7]. Among the oxidizing biocides used for the disinfection of drinking water, the chlorine has from 150 to 3000 times higher biocidal effect on the suspended bacteria in comparison with the attached cells, while the effect of chloramine was from 2 to 150 times higher [35]. The increased resistance of the attached bacteria can be explained with difficult penetration of biocide into the biofilm matrix, a low rate of bacterial growth, acquisition of resistant phenotypes and presence of resistant cells, as well with a higher bacterial density of the biofilm $[18,21$, $35,39,73]$. The frequency of mutations of biofilmassociated bacteria is significantly higher compared with planktonic compartment and an increased horizontal gene transfer is established in the biofilm, which explains the acquisition of multiple resistance to antimicrobial agents [21]. The antimicrobial resistance is intimately related to the threedimensional structure of the biofilms and with their heterogeneity; it has a multifactorial nature as a result of accumulation of a number of different acting mechanisms $[7,21]$.

The ability of drinking water-associated biofilms to provide protection against environmental stress and increased resistance to antimicrobial agents is a major challenge in implementation of technologies and tools for biofilm control in drinking water supply systems. Moreover, the resistance of mixed biofilm usually is enhanced by the coexistence of majority of species and these synergistic protective effects of the biofilm are of practical importance in selection and evaluation of the effectiveness of the various technological approaches for antimicrobial treatment [7, 34, 60, 73]. The tolerance of biofilms to higher concentrations of biocides determines the need of new strategies, which to replace or supplement the action of conventional disinfectants, for example, targeting to dispersion of the extracellular matrix or to enhancement the antimicrobial sensitivity $[5,7$, 21]. It is believed, that the extracellular DNA (eDNA) as a component of the biofilm matrix may be a promising target for biofilm control $[44,51]$. Application of enzymatic degradation of the eDNA can prevent, disperse or increase the biofilm sensitivity to antimicrobial agents $[21,66]$.

There is evidence that interspecies interactions in biofilms can radically change the response of community under toxic exposure $[34,60]$. It has 
been observed that the higher tolerance to antimicrobials mostly is a contribution of the inhabiting resistant species to protection of the entire biofilm community than a result of the selection of bacterial species acquiring resistance, while such phenomenon on the community level is absent in the mixed planktonic cultures [34]. The mechanisms involved in protection of pathogenic species by the resident microflora of the multispecies bacterial biofilms include interspecies signaling, interaction between biocide molecules and the biofilm matrix, or the physiology and genetic plasticity, associated with a spatial biofilm arrangement [56].

Considering the contribution of bacterial signaling for virulence and biofilm formation of pathogens, the researchers suggest that the inhibitors of quorum sensing (QSI) can be used for regulation. The interference into the quorum sensing system by inhibition or attenuation of bacterial communication underlies the new strategies for control of pathogenic bacteria $[12,21,31,62]$. While antibiotics kill or inhibit the growth of bacteria, the inhibitors of quorum-sensing and the attenuation agents (quorum quenchers, QQ) reduce the bacterial virulence by regulating the quorum sensing responsible for its expression [5].

Although the systems of cell-to-cell signaling used by the particular bacteria are unique in themselves, they all share a common mechanism, involving production, accumulation and detection of the signal. The effect of the inhibitors of quorum sensing is directed to at least one of these stages and causes degradation and inactivation of the quorum sensing, inhibition of the biosynthesis of QS-signal or inhibition of the detection [31]. The mechanisms to influence the water-associated biofilms through the system for interbacterial communication may include: a) enzymes that inactivate the QS-signaling molecules (signal-degrading enzymes); b) inhibitors of the receptor proteins for the signal; c) blocking the production of signaling molecules $[17,31]$. The signaling molecule $\mathrm{N}$-acyl-homoserine lactone (AHL) is a key factor in biofilm formation process [62] and the enzymes that may inactivate the synthesized signaling molecules are possible inhibitors of quorum-sensing. Therefore, the destruction or attenuation of the signaling molecules, participating in the process of interbacterial communication through appropriate enzymes is a promising approach to controlling the bacterial virulence [12].

The production of enzymes for quenching the interbacterial signaling is detected in the quorum sensing and non-quorum sensing bacteria. The presence of such enzymes in bacteria with quorum sensing activity can attenuate their quorum sensing, leading to blocking unnecessary gene expression and pathogenic phenotypes. In most non-quorum sensing bacteria the enzymatic activity for attenuating the inter-bacterial signaling is associated with capability to metabolise the signaling molecules as a source of carbon and nitrogen $[12,31]$.

The enzymes inhibiting the inter-bacterial signal are grouped into two classes. Class I includes enzymes that break down the AHL-signal molecule lactonase, acylase and paraoxonase. Lactonase is an enzyme widely distributed among bacteria, having broad substrate specificity. It is established in Bacillus, Agrobacterium, Rhodococcus, Streptomyces, Arthrobacter, Pseudomonas and Klebsiella, while the enzyme acylase is detected in Pseudomonas, Ralstonia, Comamonas, Shewanella and Streptomyces. Class II includes the enzyme oxidoreductase, that reduce the carbonyl group to a hydroxyl one. Oxidative or reducing activities of the enzyme on the side hydrocarbon chain of autoinductor AHL catalyze modification, rather than destruction of the signal molecule. Such modification may affect the specificity of AHLsignal and its recognition, thus disturbing activation of the QS-mediated genes regulated by a particular AHL. However, the limited number of enzymes for inhibiting the inter-bacterial signaling, that have been characterized, create a need of a thorough clarification of their diversity and role in microbial communication [12].

In addition to the quest for signal-degrading enzymes, the studies on the inhibitors of quorumsensing are predominantly focused on their structural similarity with the signaling molecules, thereby blocking the receptor proteins for the signal and prevent activation of target gene expression [17]. In the searching for suitable compounds it has been found that the natural furanones and their synthetic analogues successfully inhibit the bacterial signaling in vivo and in vitro. It is related to their AHL-antagonistic activity as a result of structural similarity with AHL molecule. These QS-inhibitors from furanone type are able to inhibit the biofilm related phenotypes, such as swarming, flagellar motility, extracellular production of surfactants, and as a result to control attachment and biofilm formation of some bacterial species [17]. Natural products, such as extracts of fruits (citrus, blueberries, blackberries) and extracts and oils of vegetable materials (vanilla, garlic, clove, cinnamon, 
turmeric, rosemary) have proven inhibitory effects $[10,12,31]$. It is found that vanillin (4-hydroxy-3methoxybenzaldehyde) shows significant inhibition of short-chain and long-chain AHL molecules and inhibits the biofilm formation, despite the absence of antibacterial activity [10]. Sub-inhibitory concentrations of curcumin (independently from turmeric as a source) affect the quorum sensing of Ps. aeruginosa, leading to reduced biofilm formation and production of virulence factors [31]. Inhibition of QS-systems can also be accomplished by blocking the production of signaling molecules. Since the degree of bacterial attachment is related to the content of autounductor AI-2, the interruption of its production is seen as an alternative way to control of the multi-species biofilm [17].

The diversity of bacterial species and their association in the biofilm community enhance their resistence and functional adaptability. The higher resistance of the mixed biofilms is associated with an alteration in the consortium of the participating bacterial species and their individual role, and may be due to resistence of one or two key strains. There is evidence that specific components secreted from one bacterial species in the biofilm matrix can benefit the entire population - for example, by performing a bridging function in the inter-species co-aggregation to provide stability of the biofilm matrix $[42,59]$ or the enzymes secreted by one bacterial species to confer tolerance to the other species in multi-species biofilm community [7]. The amyloids, other protective components of the matrix, are specific class of highly aggregated proteins, associated with bacterial functions as adhesion, cohesion and interaction with the host [56].

The studies of Simoes et al. (2010) show that the multi-species biofilms formed by the bacterial strains Acinetobacter calcoaceticus, Burkholderia cepatia, Mycobacterium mucogenicum, Methylobacterium sp., Sphingomonas capsulata, Staphylococcus sp., isolated from drinking water, are much more resistant to inactivation with sodium hypochlorite and biomass removal in comparison with mono-species biofilm of the individual species. Only the mono-species biofilm of Acinetobacter calcoaceticus is inactivated completely by active chlorine, while the multi-species biofilms formed with participation of all investigated bacterial strains are the most resistant. It has been also observed that the interspecies interactions in the biofilms can greatly impact the ability of the individual bacterial species to attach to and involve in the biofilm community, as well their individual susceptibility to the disinfectant [60]. Undoubtedly, the presence of pathogens in the multi-species biofilm community can be influenced by the other participating bacteria, i.e. it depends on the characteristics of the coexistening partner strains. For example, co-existence of Ps.fluorescens and S. enterica in a common biofilm enhance their survival under water chlorination by increasing their individual resistance to the disinfectant. A logical approach for limitation the virulence of biofilm is to prevent inclusion of potentially pathogenic organisms, that in turn relies on the bacterial species pre-colonizing the biofilm. Therefore, identification of such dependencies for each specific pathogen and the target elimination of the pre-colonizing species, that may have influence, can be considered as possible mechanisms for pathogen control. Many pathogenic bacteria are secondary colonizers and attach to the already existing biofilms by means of adhesins, thus, the limitation/blocking of their binding may alter the composition of the community and could make it more harmless [56].

Bacterial resistance to antibiotics (AB) is an increasing threat to public health and the environment. The latest studies show that the aquatic ecosystems are reservoir of resistant bacteria and genes of antibiotic resistance and a possible way for their transmission to human pathogens [4]. Despite the huge information about water contamination with antibiotics and their effects on the aquatic microorganisms, the contribution of the waterassociated biofilms for acquisition and dissemination of antibiotic resistance is not fully understood. It is known that the high population density and the close cell-to-cell contacts increase the probability for genetic exchange between the bacterial species and makes the biofilms hotspots for acquisition of $\mathrm{AB}$ resistance. The chronic exposure to sub-inhibitory concentrations of $\mathrm{AB}$ exerts selective pressure on the biofilm bacterial communities and promote acquisition and spread of $\mathrm{AB}$ resistance [12, 21]. At the concentrations lower than the minimal inhibitory concentration, the antibiotics act as signaling molecules to a variety of processes, as well for directing the cellular response to enhancement of horizontal transfer and dissemination of the genes of $\mathrm{AB}$ resistance. $\mathrm{A}$ greater accumulation of the genes of $\mathrm{AB}$ resistance in the biofilm than in the planktonic population is observed, but the available information on the actual capacity of the aquatic bacteria for transmission of antibiotic resistance to potentially pathogenic bacteria is still insufficient [4]. 


\section{Conclusion}

The review of the state of the research is an attempt to summarize, albeit partially, information on the dissemination of pathogenic bacteria in natural and drinking waters, focusing on the drinking water-associated biofilms. While the fate of opportunistic pathogens, such as Mycobacterium avium, Legionella pneumophila and Pseudomonas aeruginosa in water and in biofilms is relatively well understood, the some emerging pathogens, which have an increased frequency of occurance in various sources of drinking water, such as Campylobacter coli, Campylobacter jejuni, Yersinia enterocolitica, E. coli O157:H7, etc., are insufficiently studied. The studies on the biofilm-forming potential of these pathogens in natural and drinking waters are very few and the effect of their interactions with the autochtonous aquatic bacteria on their inclusion and survival in the multi-species bacterial biofilms is insufficiently understood. In addition, the data on the mechanisms for increasing the antimicrobial resistance of the pathogens incorporated into the water-associated biofilms and the possible approaches for biofilm control outline the guidelines for seeking solutions for limitation of their impact on the drinking water quality, respectively on the consumers' health.

\section{References}

1. Andersson S., G.K. Rajarao, C.J. Land, G. Dalhammar, Biofilm formation and interactions of bacterial strains found in wastewater treatment systems, FEMS Microbiol. Lett., Vol. 283, 2008, 83-90

2. Artz R.R.E., K. Killham, Survival of Escherichia coli O157:H7 in private drinking water wells: influence of protozoan grazing and elevated copper concentrations, Vol. 216, FEMS Microb. Lett., 2002, 117-122.

3. Atkinson S., C.Y. Chang, R.E. Sockett, M. Camara, P. Williams, Quorum sensing in Yersinia enterocolitica controls swimming and swarming motility, J. Bact., Vol. 188, 2006, 4, 1451-1461.

4. Balkasar J.L., J. Subirats, C.M. Borrego, The role of biofilms as environmental reservoir of antibiotic resistence, Vol. 6, Front. Microbiol., 2015, doi: 10.3389/fmicb.2015.1216.

5. Bhardwaj A.K., K. Vinothkumar, N. Rajpara, Bacterial quorum sensing inhibitors: attractive alternatives for control of infectious pathogens showing multiple drug resistance, Recent. Pat. Antiinfect. Drug. Discov., Vol. 8, 2013, 1, 68-83.
6. Bomo A.M., M.V. Storey, N.J. Ashboli, Detection, integration and persistence of aeromonads in water distribution pipe biofilms, J. Water Health, Vol. 2, 2004, 2, 83-96.

7. Bridier A., R. Briandet, V. Thomas, F. Dubois-Brissonnet, Resistance of bacterial biofilms to disinfectants: a review, Biofouling, Vol. 27, 2011, 9, 1017-1032.

8. Burmølle M., J.S. Webb, D. Rao, L.H. Hansen, S.J. Sørensen, S. Kjelleberg. Enhanced biofilm formation and increased resistance to antimicrobial agents and bacterial invasion are caused by synergistic interactions in multispecies biofilms, Appl. Environ. Microbiol., Vol. 72, 2006, 3916-3923.

9. Buswell C.M., Y.M. Herlihy, L.M. Lawrence, J.T. McGuiggan, P.D. Marsh, C.W. Keevil, S.A. Leach, Extended survival and persistence of Campylobacter spp. in water and aquatic biofilms and their detection by immunofluorescent-antibody and rRNA staining, Appl. Environ. Microbiol., Vol. 64, 1998, 733-741.

10. Choo J.P., Y. Rucayadi, J.K. Hwang, Inhibition of QS by vanilla extract, Lett. Appl. Microbiol., Vol. 42, 2006, 637-641.

11. Chekabab S.M., J. Paquin-Veillette, C.M. Dozois, J. Harel, The ecological habitat and transmission of Escherichia coli O157:H7, FEMS Microbiol. Lett., Vol. 341, 2013, 1-12.

12. Chen F., Y. Gao, X. Chen, Z. Yu, X. Li, Quorum quenching enzymes and their application in degrading signal molecules to block quorum sensing-dependent nfection, Int. J. Mol. Sci., Vol.14, 2013, 9, 17477-17500,

http://doi.org/10.3390/ijms140917477.

13. Droppo I.G., B.G. Krishnappan, S.N. Liss, C. Marvin, J. Biberhofer, Modelling sediment-microbial dynamics in the South Nation River, Ontario, Canada: Towards the prediction of aquatic and human health risk, Water Res., Vol. 45, 2011, 12, 3797-809.

14. Elias S., E. Banin, Multi-species biofilms: living with friendly neighbors, FEMS Microb. Rev. Vol. 36, 2012, 990-1004.

15. Giao M. S., N.F. Azevedo, S.A. Wilks, M.J. Vieira, C.W. Keevil, Persistence of Helicobacter pylori in heterotrophic drinking-water biofilms, Appl. Environ. Microbiol., Vol. 74, 2008, 19, 5898-5904.

16. Giaouris E., E. Heir, M. Desvaux, M. Hébraud, T. Møretrø, S. Langsrud, A. Doulgeraki, G.J. Nychas, M. Kačániová, K. Czaczyk, H. Ölmez, M. Simões, Intra- and interspecies interactions within biofilms of important foodborne bacterial pathogens, Front. Microbiol. Vol. 6, 2015, 841. 
17. Feng L., Z. Wu, X. Yu, Quorum sensing in water and wastewater treatment biofilms, J. Environ. Biol., Vol. 34, 2013, 437-444.

18. Flemming H.C., Biofilme und wassertechnologie, Teil I. Entstehung, aufbau, zusammen setzung und eigenschaf ten von biofilmen, Gas Wasser Fach., Vol. 132, 1991, 197-207.

19. Flemming H.C., S.L. Percival, J.T. Walker, Contamination potential of biofilms in water distribution systems, Water Sci. Technol., Vol. 2, 2002, 1, 271-280.

20. Hallam N.B., J.R. West, C.F. Foster, J. Simms, The potential for biofilm growth in water distribution systems, Water Res., Vol. 35, 2001, 17, 4063-4071.

21. Høiby N., T. Bjarnsholt, M. Givskov, S. Molin, O. Ciofu, Antibiotic resistance of bacterial biofilms, Int. J. Antimicrob. Agents., Vol. 35, 2010, $4,322-332$.

22. Ica, T., V. Caner, O. Istanbullu, H.D. Nguyen, B. Ahmed, D.R. Call, H. Beyenalb, Characterization of mono- and mixed-culture Campylobacter jejuni biofilms. Appl. Environ. Microbiol., Vol. 78, 2012, 4, 1033-1038.

23. Jamieson R.C., D.M. H. Lee, R. Kostaschuk, R.J. Gordon, Resuspension of sediment-associated Escherichia coli in a natural stream, J. Environ. Qual., Vol. 34, 2005, 2, 581-589.

24. Jamieson R.C., D.M. Joy, H. Lee, R. Kostaschuk, R. Gordon, Transport and deposition of sediment-associated Escherichia coli in natural streams, Water Res., Vol. 39, 2005, 12, 2665-2675.

25. Jokinen C.C., H. Schreier, W. Mauro, E. Taboada, J.L. Isaac-Renton, E. Topp, T.A. Edge, J.E. Thomas, V.P. Gannon, The occurrence and sources of Campylobacter spp., Salmonella enterica and Escherichia coli O157:H7 in the Salmon River, British Columbia, Canada, J. Water Health., Vol. 8, 2010, 2, 374-86.

26. Jones K., Campylobacters in water, sewage and the environment, J. Appl. Microbiol., Vol. 90, 2001, 68S-79S.

27. Junha T., Detection of E.coli in biofilms from pipe samples and coupons in drinking water distribution networks, Appl. Environ. Microbiol., Vol. 73, 2007, 22, 7456-7464.

28. Kim T. J., B.M. Young, G.M. Young, Effect of flagellar mutations on Yersinia enterocolitica biofilm formation, Appl. Environ. Microbiol., Vol. 74, 2008, 17, 5466-5474.

29. Klayman B. J., P.A. Volden, P.S. Stewart, A.K. Camper, Escherichia coli O157:H7 requires colonizing partner to adhere and persist in a capillary flow cell, Environ. Sci. Technol., Vol. 43, 2009, 6, 2105-2111.

30. Kot B., M. Błaszczyk, U. Kulawiec, The influence of environmental factors on survival of Y.entrocolitica O:3, Polish J. Environ. St., Vol. 14, 2005, 3, 371-374.

31. LaSarre B., M.J. Federle, Exploiting Quorum Sensing To Confuse Bacterial Pathogens, Microbiol. Mol. Biol. Rev., Vol. 77, 2013, 1, 73111.

32. Leclerc H., L. Schwartzbrod, E. Dei-Cas, Microbial agents associated with waterborne diseases, Crit. Rev. Microbiol., Vol. 28, 2002, 4, 371-409.

33. Le Dantec C., J.P. Duguet, A. Montiel, N. Dumoutier, S. Dubrou, V. Vincent, Occurrence of mycobacteria in water treatment lines and in water distribution systems, Appl. Environ. Microbiol., Vol. $68,2002,11,5318-5325$.

34. Lee K.W.K., S. Periasamy, M. Mukherjee, C. Xie, S. Kjelleberg, S.A. Rice, Biofilm development and enhanced stress resistance of a model mixed-species community biofilm, SME J., Vol. 8, 2014,. 4, 894-907.

35. LeChevallier M.W., C.D. Cawthon, R.G. Lee, Inactivation of biofilm bacteria, Appl. Environ. Microbiol., Vol. 54, 1988, 10, 2492-2499.

36. LeChevallier M.W., T.M. Babcock, R.G. Lee, Examination and characterization of distribution system biofilms, Appl. Envir. Microbiol., Vol. 53, 1987, 12, 2714-2724.

37. LeChevallier M.W., Coliform regrowth in drinking water: A review, J. $A W W A, 1990,74-86$.

38. Lethola M., E. Torvinen, J. Kusnetsov, T. Pitkanen, L. Maunula, C.H. von Bonsdorff, P. Martikainen, S. Wilks, C.W. Kleevil, I. Meittinen, Mycobacterium avium, Legionella pneumophilla, Escherichia coli and caliciviruses in drinking waterassociated biofilms grown under high-shear turbulent flow, Appl. Environ. Microbiol., Vol. 73, 2007, 9, 2854-2859.

39. Lewis K., Riddle of Biofilm Resistance, Antimicrob. Agents Chemoth., Vol. 45, 2001, 4, 4999-1007.

40. Malham S.K., P. Rajko-Nenow, E. Howlett, K.E. Tuson, T.L. Perkins, D.W. Pallett, H. Wang, C.F. Jago, D.L. Jonese, J.E. McDonald, The interaction of human microbial pathogens, particulate material and nutrients in estuarine environments and their impacts on recreational and shellfish waters, Environ. Sci. Proc. Impacts, Vol. $16,2014,2145-2155$. 
41. Marti R., V.P Gannon, C. Jokinen, M. Lanthier, D.R. $\quad$ Lapen, N.F. Neumann, N.J. Ruecker, A. Scott, G. Wilkes, Y. Zhang, E. Topp, Quantitative multi-year elucidation of fecal sources of waterborne pathogen contamination in the South Nation River basin using bacteroidales microbial source tracking markers, Water Res., Vol. 47, 2013, 7, 2315-2324.

42. Min K.R., A.H. Rickard, Co-aggregation by the freshwater bacterium Sphingomonas natatoria alters dual-species biofilm formation, Appl. Environ. Microbiol, Vol. 75, 2009, 12, 3987-3997.

43. Momba M.N.B., R. Kfir, S.N. Vente, T.E. Cloete, An overview of biofilm formation in distribution systems biofilms and its impact on the deterioration of water quality, Water SA, Vol. 26, 2000, 1, 59-66.

44. Montanaro L., A. Poggi, L. Visai, S. Ravaioli, D. Campoccia, P. Speziale, C.R. Arciola, Extracellular DNA in biofilms, Int. J. Artif. Organs., Vol. 34, 2011, 9, 824-831.

45. Moritz M., H.C. Flemming, J. Wingender, Integration of Pseudomonas aeruginosa and Legionella pneumophila in drinking water biofilms grown on domestic plumbing materials, Int. J. Hyg. Environ. Health, Vol. 213, 2010, 3, 190-197.

46. Moritz M., Integration of hygienically relevant bacteria in drinking water biofilms grown on domestic plumbing materials, 2011, PhD thesis, https://duepublico.uni-duisburg-essen.del

Diss_Moritz.pdf

47. Ndiongue S., P.M. Huch, R.M. Slawson, Effects of temperature and biodegradable organic matter on control of biofilms by free chlorine in a model drinking water distribution system, Water Res., Vol. 39, 2005, 953-964.

48. Norman S.A., R.C. Hobbs, S. Wuertz, A. Melli, L.A. Beckett, N. Chouicha, A. Kundu, W.A. Miller, Fecal pathogen pollution: sources and patterns in water and sediment samples from the upper Cook Inlet, Alaska ecosystem, Environ. Sci. Proc. Impacts, Vol. 15, 2013, 1041-1051.

49. Norton C., M. LeChevallier, J.O. Falkinham, Survilval of Mycobacterium avium in a model distribution system, Water Res., Vol. 38, 2004, 1457-1466.

50. Novoslavskij A., L. Serniene, S. Ramonaite, G. Zakariene, M. Malakauskas, Comparison of antimicrobial resistence and biofilm formstion of Yersinia enterococlitica 4/O:3 strains isolated from pig production chain and patients clinical specimens, Vet. Med. Zoot., Vol. 62, 2013, 84, 62-67.

51. Okshevsky M., R.L. Meyer, The role of extracellular DNA in the establishment, maintenance and perpetuation of bacterial biofilms, Crit. Rev. Microbiol., Vol. 41, 2015, 3, 341-52.

52. Reeser R.J., R.T. Medler, S.J. Billington, B.H. Jost, L.A. Joens, Characterization of Campylobacter jejuni biofilms under defined growth conditions, Appl. Environ. Microbiol., Vol. 73, 2007, 6, 1908-1913.

53. Rendueles O., J.M. Ghigo, Multi-species biofilms: how to avoid unfriendly neighbors. FEMS Microb. Rev., Vol. 36, 2012, 972-989.

54. Ren D., J.S. Madsen, S.J. Sørensen, M. Burmølle, High prevalence of biofilm synergy among bacterial soil isolates in cocultures indicates bacterial interspecific cooperation. ISME J., Vol. 9, 2015, 81-89

55. Ryu, J.-H., Kim, H. \& Beuchat, L. R. 2004. Attachment and biofilm formation by Escherichia coli $0157: H 7$ on stainless steel as influenced by exopolysaccharide production, nutrient availability, and temperature. J. Food Prot., Vol. 67, 2004, 21232131.

56. Sanchez-Vizuete P., $\quad$ B. Orgaz, S. Aymerich, D. Le Coq, R. Briandet, Pathogens protection against the action of disinfectants in multispecies biofilms, Front. Microbiol., Vol. 6, 2015, doi: 10.3389/fmicb.2015.00705.

57. Schets F. M., M. During, R. Italiaander, L. Heijnen, S.A. Rutjes, W.K. Van der Zwalew, A.M. de Roda Husman, E.coli O157:H7 in drinking water from private water supplies in the Netherland. Water Res., Vol. 39, 2005, 4485-4493.

58. Simões L.C., M. Simões, M.J. Vieira, Biofilm interactions between distinct bacterial genera isolated from drinking water, Appl. Environ. Microbiol., Vol. 73, 2007, 19, 6192-6200.

59. Simões L.C., M. Simões, M.J. Vieira, Intergeneric coagregation among drinking water bacteria: evidence of a role for Acinetobacter calcoaceticus as a bridging bacterium, Appl. Environ. Microbiol., Vol. 74, 2006, 4, 1259-1264.

60. Simões L.C., M. Simões, M.J. Vieira, Influence of the diversity of bacterial isolates from drinking water on resistance of biofilms to disinfection, Appl. Environ. Microbiol, Vol. 76, 2010, 19, 6673-6679.

61. Storey M.V., J. Långmark, N.J. Ashbolt, T.A. Stenström, The fate of legionellae within distribution pipe biofilms: measurement of their persistence, inactivation and detachment, Water Sci. Technol., Vol. 49, 2004, 269-275.

62. Tan C.H., K.S. Koh, C. Xie, J. Zhang, X.H. Tan, G.P. Lee, Y. Zhou, W.J. Ng, Community 
quorum sensing signalling and quenching: microbial granular biofilm assembly, NPJ Biofilms and Microbiomes, Vol. 1, 2015, 15006; doi:10.1038/npjbiofilms.2015.6;

63. Torvinen E., M. Lethola, P. Martikainen, I. Meittinen, Survival of Mycobacterium avium in drinking water biofilms affected by water flow velocity, availability of phosphorous and temperature, Appl. Environ. Microbiol., Vol. 73, 2007, 19, 6201-6207.

64. Torvinen E., S. Suomalainen, M. Lehtola, I. Miettinen, O. Zacheus, L. Paulin, M.L. Katila, P.J. Martikainen, Mycobacteria in water and loose deposits of drinking water distribution systems in Finland, Appl. Environ. Microbiol., Vol. 70, 2004, 4, 1973-1981.

65. Teh K.H, S. Flint, N. French, Biofilm formation by Campylobacter jejuni in controlled mixed-microbial populations, Int. J. Food Microbiol., Vol. 143, 2010, 3, 118-124.

66. Tetz V.V., G.V. Tetz, Effect of Extracellular DNA Destruction by DNase I on Characteristics of Forming Biofilms, DNA Cell Biol., Vol. 29, 2010, 8, 399-405.

67. Uhlich G.A., D.P. Rogers, D.A. Mosier, Escherichia coli serotype O157:H7 retention on solid surfaces and peroxide resistance is enhanced by dual-strain biofilm formation, Foodborne Path. Dis., Vol. 7, 2010, 8, 935-943.

68. Van der Kooij D., J.S. Vrouwenvelder, H.R. Veenendaal, Elucidation of biofilm formation process in water treatment and distribution using the unified biofilm approach, Water Sci.Technol., Vol. 47, 2003, 5, 83-90.

69. Van der Kooij D., H.R. Veenendaal, N.P. Slaats, D. Vonk (2002). Biofilm formation and multiplication of Legionella on synthetic pipe materials in contact with treated water under static and dynamic conditions, In: Legionella, (Reinhard Marre. Ed.), ASM Press, Washington DC, 176-180.

70. Vital M., D. Stucki, T. Egli, F. Hammes, Evaluating the growth potential of pathogenic bacteria in water, Appl. Environ. Microbiol., Vol. 79, 2004, 19, 6477-6484.
71. Waage A.S., T. Vardund, V. Lund, G. Kapperud, Detection of low numbers of pathogenic Yersinia enterocolitica in environmental water and sewage samples by nested PCR, Appl. Environ. Microbiol., Vol. 87, 1999, 814-821.

72. Walker J.T., C.W. Mackerness, J. Roger, Heterogeneous mosaic biofilm - a heaven for waterborne pathogens, In: Microbial biofilms, (Lappin-Scott HM, J.W. Costerton, Eds.), 1995, Cambridge University Press, 196-204.

73. Wang R, N. Kalchayanand, J.W. Schmidt, D.M. Harhay, Mixed biofilm formation by Shiga toxin-producing Escherichia coli and Salmonella enterica serovar Typhimurium enhanced bacterial resistance to sanitization due to extracellular polymeric substances, J. Food Prot., Vol. 76, 2013, 9, 1513-1522.

74. Wanjugi P., V.J. Harwood, The influence of predation and competition on the survival of commensal and pathogenic fecal bacteria in aquatic habitats, Environ. Microb., Vol. 15, 2013, 2, 517 526.

75. Willams M.M., E.E. Braun-Howland, Growth of Escherichia coli in model distribution system biofilms exposed to hypochlorous acid or monochloramine, Appl. Environ. Microbiol., Vol. 69, 2003, 9, 5463-5271.

76. Wricke B., A. Korth, Petzoldt, M. Kruger, Change of bacterial water quality in drinking water distribution systems working with or without low chlorine residual, Water Sci.Technol.:WS, Vol. 2, 2002, 3, 275-281.

77. Yu J., D. Kim, T. Lee, Microbial diversity in biofilms on water distribution pipes of different materials. Water Sci. Technol., Vol. 61, 2010, 1, 163-171.

78. Zhang W., C. Li, Exploiting quorum sensing interfering strategies in gram-negative bacteria for the enhancement of environmental applications, Front. Microbiol, 2016, http://dx.doi.org/10.3389/ fmicb. 2015.01535

79. World Health Organization, Water Quality: Guidelines, Standards and Health, (L. Fewtrell, J. Bartram, Eds.), IWA Publishing, London, UK, ISBN: 190022228 


\title{
ПАТОГЕННИ БАКТЕРИИ ВЬВ ВОДИ И В АСОЦИИРАНИ С ПИТЕЙНАТА ВОДА БИОФИЛМИ
}

\author{
Звездимира Цветанова, Христо Найденски
}

Резюме. Обзорът разглежда разпространението на пренасяните по воден път бактериални патогени в природните води, механизмите на пренос в питейните води и ролята на асоциираните с водата биофилми за тяхното оцеляване и/или растеж. Обобщена е информацията за биофилм-образуващата способност на патогените в питейна вода и ролята на междувидовите взаимодействия за включване и участие на патогенните бактерии в биофилмовото съобщество. Дискутирано е значението на биофилмите за повишаване на резистентността на патогените към антимикробни средства.

Ключови думи: бактериална устойчивост, биофилм, патогенни бактерии, питейна вода

\section{Assist. Prof. Zvezdimira Tsvetanova, PhD}

The Stephan Angeloff Institute of MicrobiologyKey

E-mail: zvezdimira@yahoo.com

\section{Prof. Hristo Najdenski, DVM, DSc, Corresp. member of BAS}

The Stephan Angeloff Institute of Microbiology

E-mail: hnajdenski@abv.bg 